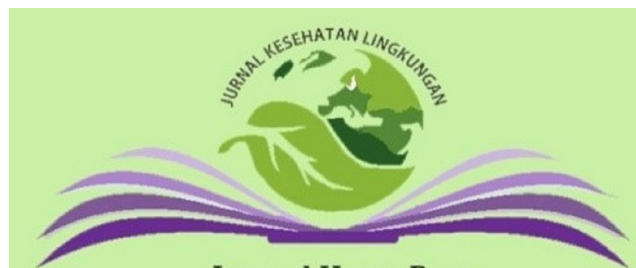

Journal Home Page:

https://e-journal.unair.ac.id/JKL

\section{Jurnal Kesehatan Lingkungan}

Vol. 13 No. 2

DOI: $10.20473 /$ jkl.v13i2.2021.64-71

ISSN: 1829 - 7285

E-ISSN: 2040 - 881X

\title{
BASIC HOUSE SANITATION IN SWAMP BANKS IN PEMULUTAN
}

Inoy Trisnaini ${ }^{1 *}$, Imelda Gernauli Purba ${ }^{1}$, Amrina Rosyada ${ }^{2}$

${ }^{1}$ Environmental Health Program, Public Health Faculty, Sriwijaya University, Indralaya Ogan Ilir 30662, Indonesia

${ }^{2}$ Public Health Program, Public Health Faculty, Sriwijaya University, Indralaya Ogan Ilir 30662, Indonesia

\section{Corresponding Author:}

*)inoytrisnaini@fkm.unsri.ac.id

\section{Article Info}

Submitted

In reviewed

: 14 February 2021

Accepted

16 March 202

Available Online

Keywords : Sanitation, clean water, latrine,

garbage, sewerage

Published by Fakultas Kesehatan Masyarakat Universitas Airlangga

Abstract

Introduction: Based on the health profile of Ogan Ilir District, in 2014. Pemulutan was the subdistrict with the lowest number of households with clean and healthy living behaviour of all subdistricts in the Ogan Ilir Regency. Only 21.9\% of households in Pemulutan had clean and healthy living behaviour, while the remaining $78.1 \%$ households did not have clean and healthy living behaviour. The purpose of this study was to assess the basic sanitation of houses in the swamp banks of Pemulutan. Methods: This research utilized a quantitative approach using a survey method. Research was conducted in five villages in Pemulutan with the cluster random sampling method. The samples in this study consisted of 140 households. Results and Discussion: It was found that $70.7 \%$ of respondents used rivers or swamps as clean water sources, even though $60 \%$ of the clean water sources used did not meet health requirements. Furthermore, 97.1\% of defecation facilities did not meet health requirements, $89.3 \%$ used latrine did not meet health requirements, and $83.6 \%$ of sewerage did not meet health requirements. Conclusion: The basic sanitation conditions of the community houses in Pemulutan have not met health requirements. To overcome this, public knowledge and awareness of the role of home sanitation in supporting the health of family members should be increased, along with support from the local government 


\section{INTRODUCTION}

Diarrhea is a health problem in many developing countries, one of which is Indonesia, because it often occurs in the form of outbreaks, and is accompanied by high mortality. The World Health Organization notes that 100,000 Indonesian children die from diarrhea every year. Results of the Basic Health Research (2007) showed that diarrhea was the main cause of mortality for children under five in Indonesia (1). Pemulutan had been the subdistrict with the third highest number of diarrhea cases in all age groups, with 545 cases of diarrhea (2). There are several factors related to the incidence of diarrhea, namely, water contaminated with feces, lack of cleanliness facilities, and improper food preparation and storage (3). Based on the health profile of the Ogan Ilir District, Pemulutan was the sub-district with the lowest number of households with clean and healthy living behavior in the Ogan Ilir Regency. $21.9 \%$ of households had clean and healthy living behaviour, while the remaining $78.1 \%$ did not have clean and healthy living behavior (2). Diarrhea is an environmentally-based disease. Several factors related to the incidence of diarrhea include inadequate supply of clean water, water contaminated by feces, lack of sanitary facilities (disposal of unhygienic feces), personal hygiene, and bad environment sanitation. In essence, optimum environmental health conditions have a positive effect on the realization of optimal health status. Environmental sanitation includes the following aspects: housing, garbage disposal, disposal of human waste (feces), provision of clean water, disposal of waste water, and livestock pens (4).

Results of field observations showed that the sanitary conditions of houses in Pemulutan were still poor in regards to the quality of water used for household needs, as well as sewage drains. There were also still people who defecated in rivers and swamps. The first step in overcoming these issues is understanding the distribution of basic sanitation conditions in existing homes by using a Geographical Information System (GIS). The information obtained from this can later become the basis for housing sanitation improvement programs and activities. This is because a GIS produces reliable data since spatial information is expressed in accordance with actual field conditions, and will result in optimal management methods (5). The purpose of this study was to determine the distribution of basic sanitation conditions in households in Pemulutan using a GIS.

\section{METHODS}

This study was done with a quantitative approach using the survey method. Quantitative data was primary data collected based on observations regarding basic sanitation facilities for clean water, healthy latrines, garbage collection and waste water disposal. The research was conducted in five villages in Pemulutan with the criteria being on a swamp / riverbank. The study population was all 10,262 households in Pemulutan.

A sample of 140 was obtained with the estimation formula. The sample was selected using the cluster random sampling technique. The village selection clusters were the five villages on the edge of swamps or rivers with environmental conditions that tended to be homogeneous, namely Teluk Kecapi, Pelabuhan Dalam, Pemulutan Ulu, Pemulutan Ilir, and Muara Dua. The sample inclusion criteria were residents who lived in the swamps of Pemulutan, with one individual representing each household. Quantitative data was primary data collected based on observations regarding basic sanitation facilities for clean water, healthy latrines, garbage collection, and waste water disposal. Secondary data were obtained from the Pemulutan District Profile.

Data were collected using a questionnaire and observation sheet. The observation sheet was used to describe the basic sanitation of the settlements. The type of data analysis used was spatial analysis. Activities carried out at this stage were with the map overlay or map overlays method through the Arc program Geographical Information System (GIS). One of the advantages of analysis with an overlay map is the visible visualization of several variables that can be presented spatially. One of the overlays carried out in this study was a map of the research area with survey data, which included basic sanitation characteristics of access to clean water, healthy latrines, garbage collection, and waste water disposal.

\section{RESULTS}

\section{Respondent Characteristics}

Table 1 shows that most respondents (31.4\%) graduated from elementary school, and $85.7 \%$ of respondents were housewives or did not work formally. As for personal hygiene, almost half of respondents who were mothers $(40.7 \%)$ had poor application of daily personal hygiene, especially in hand washing behavior. 
Table 1. Distribution of Respondent Characteristics

\begin{tabular}{lcc}
\hline \multicolumn{1}{c}{ Characteristics } & $\mathbf{n}=\mathbf{1 4 0}$ & $\mathbf{\%}$ \\
\hline $\begin{array}{l}\text { Mother's Education } \\
\text { Did not go to school / did not complete } \\
\text { elementary school }\end{array}$ & 5 & 3.6 \\
Graduated from elementary school & 44 & 31.4 \\
Graduated from Junior High School & 42 & 30 \\
Graduated from senior High School & 41 & 29.3 \\
Bachelor & 8 & 5.7 \\
\hline Mother's Job & & \\
$\quad$ Housewife & 120 & 85.7 \\
Entrepreneur & 18 & 12.9 \\
Government employees & 2 & 1.4 \\
\hline Mother's Personal Hygiene & & \\
$\quad$ Bad & 57 & 40.7 \\
Good & 83 & 59.3 \\
\hline
\end{tabular}

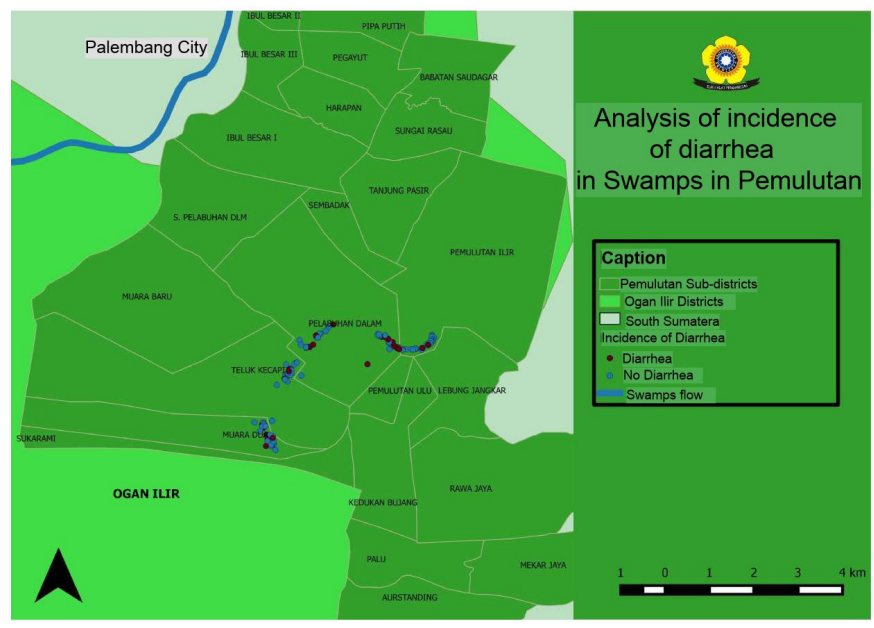

Figure 1. Distribution of Diarrhea Incidence

Table 2 shows that out of the 140 toddlers surveyed, $24.5 \%$ were 4 years old. Table 2 also shows $78.6 \%$ of children under five had not experienced diarrhea in the last month, and $56.4 \%$ of mothers who had toddlers with diarrhea brought their children to midwives for medical first aid. Figure 1 shows that the incidence of diarrhea among children under five in the past month was evenly distributed between the five villages.

Table 2. Distribution of Diarrhea Incidence in Toddlers

\begin{tabular}{lcc}
\hline \multicolumn{1}{c}{ Characteristics } & $\mathbf{n}=\mathbf{1 4 0}$ & $\mathbf{\%}$ \\
\hline Toddlers Age & & \\
1 Year & 26 & 18.5 \\
2 Year & 47 & 33.5 \\
3 Year & 33 & 23.5 \\
4 Year & 34 & 24.5 \\
5 Year & 0 & 0 \\
\hline Diarrhea in the Last 1 Month & & \\
Yes & 30 & 21.4 \\
No & 110 & 78.6 \\
\hline First Aid When Children Have Diarrhea & & \\
Doctor & 1 & 0.7 \\
Public health center & 49 & 35 \\
Midwife & 79 & 56.4 \\
self-medicate & 11 & 7.9 \\
\hline
\end{tabular}

\section{Sanitation of Clean Water Sources}

Table 3 shows that the majority of respondents $(70.7 \%)$ used river or swamp water as a source of water for their daily needs, in this case for bathing, washing, toilet activities, and washing food ingredients. Although, the majority of the water sources (84\%) did not meet physical health requirements in regards to their smell, taste, and color.

Table 3. Distribution of Clean Water Sources

\begin{tabular}{lcc}
\hline \multicolumn{1}{c}{ Characteristics } & $\mathbf{n = 1 4 0}$ & $\mathbf{\%}$ \\
\hline Clean Water Sources & 38 & 27.1 \\
Local Water Company & 3 & 2.1 \\
Well & 99 & 70.7 \\
River/Swamp & & \\
Water Quality & 84 & 60 \\
$\quad$ Not eligible & 56 & 40 \\
Eligible & & \\
\hline
\end{tabular}

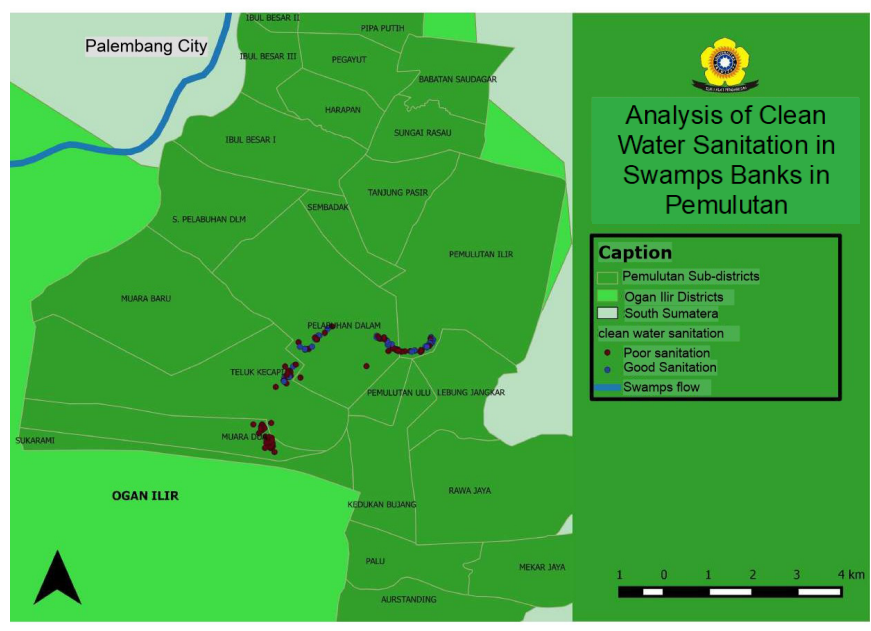

Figure 2. Distribution of Clean Water Source Sanitation Distribution

In Figure 2, it can be seen that the majority of the water sources used by respondents for their daily needs did not meet physical health requirements, especially in Muara Dusa where all respondents used water sources of poor quality.

\section{Sanitation of Latrine}

Table 4 shows that almost half of respondents (46.4\%) did not have a family toilet as a means for defecating or urinating. The remaining $53.6 \%$ of respondents had the habit of defecating in open land, namely gardens and rivers or swamps. $60 \%$ of respondents who did not have family latrines chose to defecate in the garden. 136 respondents $(60 \%)$ had the habit of defecating or urinating in the latrine or other facilities that did not meet health requirements, as seen in Figure 3. 
Table 4. Latrine Sanitation Distribution

\begin{tabular}{lcc}
\hline \multicolumn{1}{c}{ Characteristics } & $\mathbf{n}=\mathbf{1 4 0}$ & $\mathbf{\%}$ \\
\hline Latrine Ownership & & \\
$\quad$ No & 65 & 46.4 \\
$\quad$ Yes & 75 & 53.6 \\
\hline Latrine Sanitation & 136 & \\
$\quad$ Not Eligible & 4 & 2.9 \\
$\quad$ Eligible & $\mathbf{n}=\mathbf{6 5}$ & $\mathbf{\%}$ \\
Location of Defecation Other than Latrines & 39 & 60 \\
$\quad$ Garden & 26 & 40 \\
$\quad$ River/Swamp & & \\
\hline
\end{tabular}

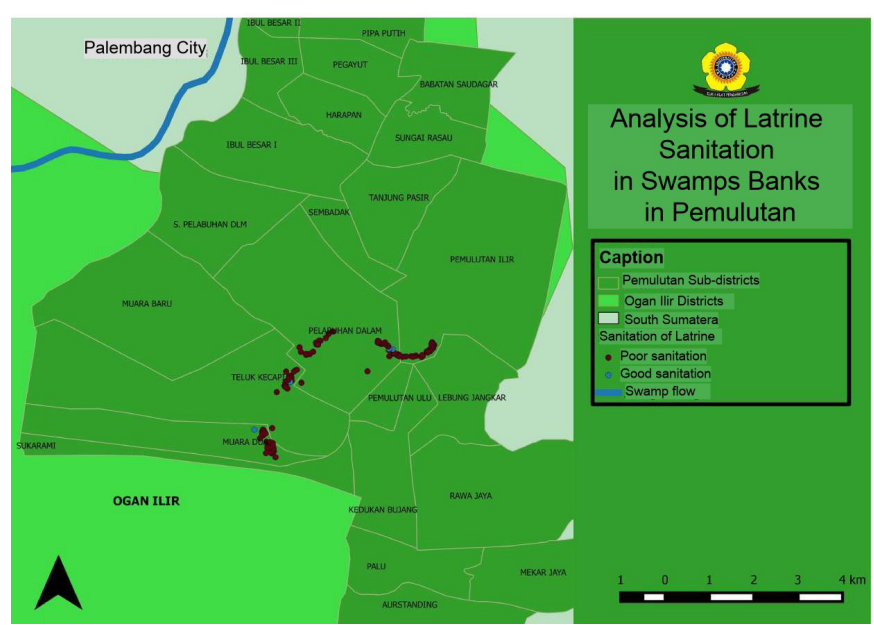

Figure 3. Distribution of the Distribution of Latrines

\section{Sanitation of Temporary Waste Disposal Site}

Table 5 shows that more than half of respondents $(67.1 \%)$ did not have a temporary waste disposal site, while the rest $(32.9 \%)$ had temporary waste disposal sites. The majority of the temporary waste disposal sites used $(60.8 \%)$ were trash baskets. Of the 94 respondents $(67.1 \%)$ who did not have a temporary waste disposal site at home, $46.8 \%$ disposed of their waste by burning it, while $47.8 \%$ threw their waste into the river. Overall, $89.3 \%$ of respondents had temporary waste disposal sites that did not meet health requirements, as seen in Figure 4.

Table 5. Distribution of Temporary Waste Disposal Site Sanitation

\begin{tabular}{lcc}
\hline \multicolumn{1}{c}{ Characteristic } & $\mathbf{n}=\mathbf{1 4 0}$ & $\mathbf{\%}$ \\
\hline Waste Disposal Site Ownership & 94 & 67.1 \\
No & 46 & 32.9 \\
Yes & 125 & \\
\hline Sanitation of Waste Disposal Site & 89.3 \\
Not Eligible & 15 & 10.7 \\
Eligible & $\mathbf{n}=\mathbf{4 6}$ & $\mathbf{\%}$ \\
\hline Type of Waste Disposal Site & 28 & 60.8 \\
Wastebasket & 16 & 34.7 \\
Plastic bags & 2 & 4.5 \\
Reservoir & $\mathbf{n}=\mathbf{9 4}$ & $\mathbf{\%}$ \\
\hline Other landfills & 44 & 46.8 \\
Burned & 5 & 5.4 \\
Buried soil & 45 & 47.8 \\
Dumped into the river & &
\end{tabular}

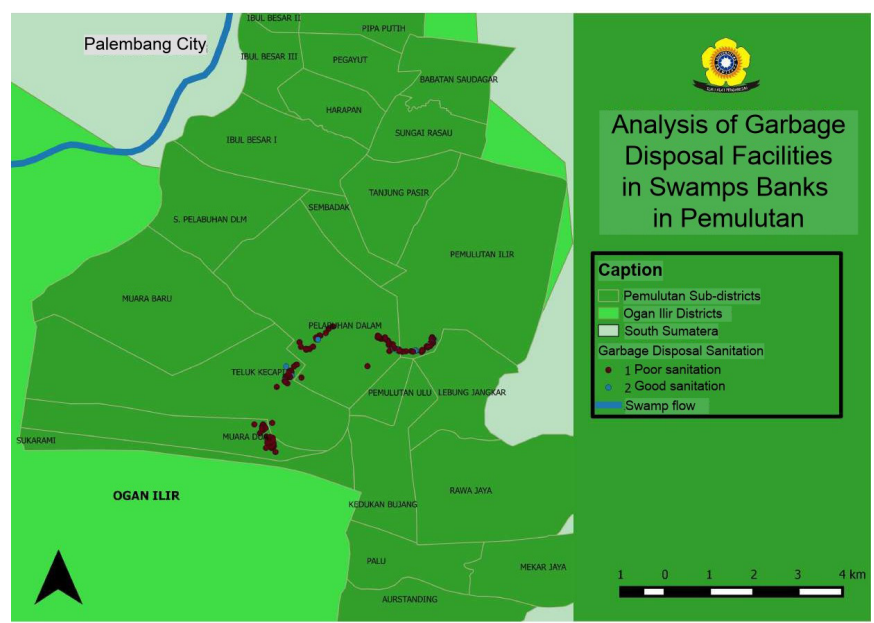

Figure 4. Distribution of Garbage Disposal Facilities

\section{Sanitation of Sewerage}

Table 6 and Figure 5 show that the majority of the respondents' sewerage (83.6\%) did not meet health requirements. In Pelabuhan Dalam and Muara Dua, all sewerage did not meet health requirements.

Table 6. Distribution of Sewerage Sanitation

\begin{tabular}{lccc}
\hline & Characteristics & $\mathbf{n = 1 4 0}$ & $\mathbf{\%}$ \\
\hline Not eligible & 117 & 83.6 \\
Eligible & 23 & 16.4 \\
\hline
\end{tabular}

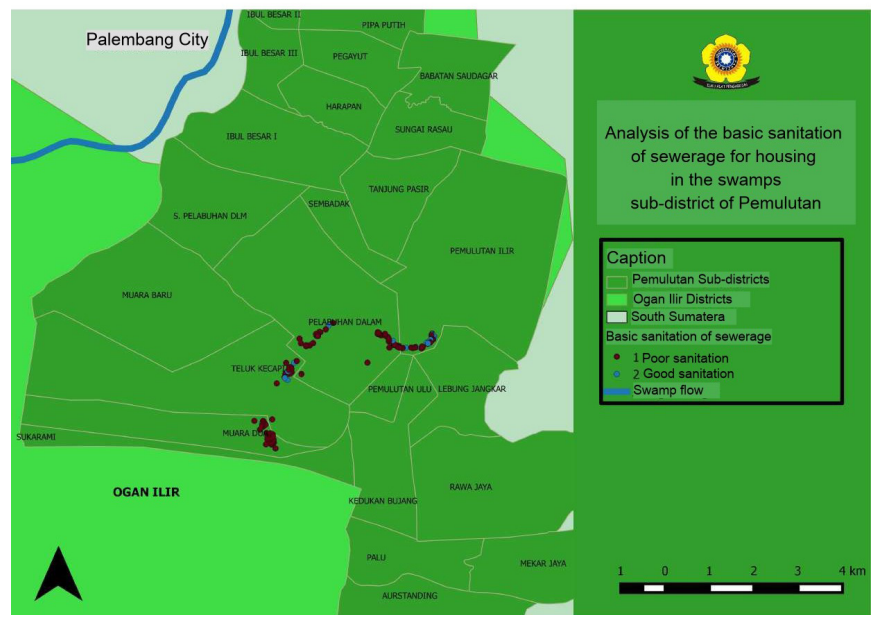

Figure 5. Distribution of Sewerage

\section{DISCUSSION}

Based on the results of the study, almost half of the respondents who were mothers $(40.7 \%)$ had poor application of daily personal hygiene, especially in hand washing behavior. The behavior of mothers in relation to health plays a big role in the health of other family members. For example, the habit of not washing hands with soap after defecating is a habit that can harm the child, especially when the mother cooks food and feeds her child, as the food can be contaminated with germs 
which can cause diarrhea (6). Various studies have shown that there is a significant relationship between maternal personal hygiene and the incidence of diarrhea in children under five in the family. Research conducted in Primary Health Care of Tasikmadu showed that toddlers who lived in homes with bad personal hygiene conditions had 6,287 times the risk of suffering from diarrhea than children who lived in homes with good personal hygiene (7). In addition, a research conducted in Primary Health Care of Karanganyar also concluded that the variables correlated with diarrhea cases in children included clean water facilities $(p=0.022)$, conditions of drinking water facilities $(p=0.010)$, and toilet conditions $(p=0.010)$ (8).

The results of this study showed that most respondents $(70.7 \%)$ still used river water or swamp water as a source of water for their daily needs, specifically for bathing, washing, toilet activities, and washing food ingredients. 84 respondents $(60 \%)$ used clean water facilities that did not meet health requirements, while the remaining $56(40 \%)$ used clean water sources that met health requirements. There was a relationship between the environmental sanitation variable $(p=0.001)$ and the mother's individual hygiene variable $(p=0.002)$ with the incidence of diarrhea in children under five. The unavailability of clean water greatly influences the incidence of diarrhea, thus clean water is needed to reduce the occurrence of diarrhea. Research results showed that there was a correlation between the microbiological quality of dug well water and the incidence of diarrhea. Causative infectious bacteria is transmitted by the fecal oral route. Process transmission can occur through washing cooking utensils with unclean water and drinking uncooked water (9). The requirements for clean water quality are based on the Regulation of Ministry of Health of Republic Indonesia No. 416 Year 1990 about Requirements and Control of Drinking Water by looking at physical, biological, chemical, and radioactive parameters (10). The need for clean water sources referred to here is dug wells, in terms of location and construction. Dug wells should have a minimum distance of 11 meters from the source of bacteriological pollutants, be on sloping land above the source of the pollutant, be in the soil layer that contains water throughout all seasons, and be located in a floodfree area. In accordance with health requirements, wells should be watertight, 3 (three) meters deep to avoid seepage of dirty water from the ground, and equipped with a well lip as high as 7 (seven) meters from the ground to prevent used water from entering into wells. Water should be able to be retrieved in such a way that it does not cause pollution into the well. The thickness of the well walls should be in accordance with the diameter of the well. The floor should either be a square or a circle, watertight, and with a size of 1 meter from the edge of the well. There should also be a drain on the well floor to drain used water (11).

Nearly half of respondents $(46.4 \%)$ did not have a family latrine for defecating or urinating. 53.6\% of all respondents had the habit of defecating in open land, namely gardens, rivers, or swamps, and $60 \%$ of respondents who did not have family latrines chose to defecate in the garden. 136 respondents $(60 \%)$ had the habit of defecating or urinating in the latrine or other facilities that did not meet health requirements. There are several factors that influence latrine use behavior. The results of a study conducted in Tambak Lorok Semarang showed that there was a relationship between age, knowledge, attitude, education, latrine ownership, the number of family members, and the behavior of the head of the household in using the latrine (12). Latrine ownership and defecation behavior can also be factors causing the incidence of diarrhea in family members (13). Proper sanitation can be achieved by meeting the requirements for healthy latrines. If the toilet facilities are privately owned or shared, then goose neck toilets should be used, and the place for final disposal of feces should be a septic tank or wastewater disposal facility. The following are the requirements for healthy latrines according to Ministry of Health of Republic Indonesia: does not pollute drinking water sources; the location of the sewage collection hole is at least 10 meters from the well; odorless and prevents insects from entering the pit; urine and cleaning water used to flush feces does not pollute the surrounding soil; easy to clean and safe to use; has a protective wall and roof; watertight floors; latrine area is sufficient or not too low; enough ventilation; water, soap, and cleaning tools are available (14).

Research in Musi River show the use of Tripikon as an alternative to using septic tanks in riverbanks and swamps. Tripikon is a feces processing plant that can be used in watery areas and riverbanks. Tripikon has the same function as septic tanks, and their only difference is in their design and manufacture. The processing system used by Tripikon is both aerobic and anaerobic. The basic concept of the treatment is to use three pipes, namely small pipes for the toilet inlet, medium pipes for the biological decomposition process, and large pops for the liquid waste overflow. The three pipes are arranged concentrically. The performance of these two systems still needs to be studied further, however. This system has the potential to be developed into an 
alternative wastewater treatment (15). More than half of the respondents in this study $(67.1 \%)$ did not have a temporary waste disposal site, while the rest (32.9\%) had a temporary waste disposal site. The majority of the temporary waste disposal sites used $(60.8 \%)$ were trash baskets. The 94 respondents $(67.1 \%)$ who did not have a temporary waste disposal site at home disposed of their waste by burning it $(46.8 \%)$ or throwing it into the river $(47.8 \%)$. Overall, $89.3 \%$ of respondents had temporary waste disposal sites that did not meet health requirements. Several studies have shown a correlation between temporary waste disposal sites and diarrhea.

Research in Primary Health Care of Adiwerda showed the incidence of diarrhea has a significant relationship with latrine facility conditions, SPAL, and the bacteriological quality of the water $(p=0.02, p=0.03$, and $p=0.02$ ), and was not associated with garbage disposal facilities $(p=0.063)$. Latrine conditions that do not meet these requirements can pollute the surrounding environment, especially through contamination by human waste. Environmental pollution by human will spread diseases such as diarrhea. The mechanism for diarrheal disease is due to the inadequate sanitary condition of the latrine, which can lead to the transmission of diseasecausing bacteria in the feces to the host. Bacteria can be transferred through various sorts of media such as water, hands, insects, and the soil. Furthermore bacteria can contaminate food and drinks (16).

Research in Martapura District has offered a technological solution to overcome the issue of proper fecal disposal through research in Banjar Regency. The research was conducted using a literature study, field observation, and interviews. Fecal management can be done by using T-Pikon-H for the floating houses in the river area of the Martapura district, while septic tanks can be used for the land houses. There were 383 landed houses and 215 floating houses, and the planning was conducted in two stages for each house in order to achieve the 100\% Open Defecation Free (ODF) target in Murung Keraton by 2021 (17). Human settlements are one of the largest producers of waste from household activities. Solid waste that is not managed properly and simply thrown away is a problem for public health because the waste can become a den of disease vectors (18).

The results of this study indicated that the majority of the respondents' sewerage $(83.6 \%)$ did not meet health requirements, especially in Pelabuhan Dalam and Muara Dua, where all sewerage did not meet the requirements. Several factors contribute to the poor sanitation of sewerage. Other studies suggest people are economically unable to make the sewerage permanently and because they think this is not a basic necessity that can interfere with health (19). They assumed that the gutter would soon sink into the ground. To change this mindset, what is necessary is the fulfillment of basic needs (20). The condition of drainage channels in sewerage is bad, and waste tends to be disposed of directly in water bodies. This will exacerbate the pollution load in water bodies (21-22).

Waste and waste disposal activities into rivers are generally carried out by residents who live and/or conduct activities along the river. Hence, to reduce the amount of garbage and waste disposed of into the river, a larger emphasis needs to be placed on the people who live and/or operate near the river. Efforts to control river pollution caused by garbage and waste are still limited. These efforts are also inhibited by low public awareness in protecting the environment, as well as lack of enforcement law for environmental pollution offenders. Therefore, a comprehensive and holistic approach is needed for controlling river pollution caused by garbage and waste, in order to maintain good environmental and water quality (23). In general, changes in the community expected from a public campaign include increased awareness (awareness), increased interest (interest), growing needs (demand), and the existence of participation and action (action). For this reason, it is necessary to build public awareness of the importance of maintaining home sanitation, and the first step is to increase community knowledge (24). In addition, Community-Based Total Sanitation (CBTS) is an approach that can be taken to improve personal hygiene and environmental sanitation through community empowerment by means of triggering (25).

\section{ACKNOWLEDGEMENTS}

Many thanks to the Sriwijaya University Research and Community Service Institute for funding the implementation of this research.

\section{CONCLUSION}

The majority of respondents $(70.7 \%)$ used river or swamp water as a source of water for their daily needs. The majority of the water sources used $(84 \%)$ did not meet health requirements, and $46.4 \%$ of respondents did not have a family toilet as a means of defecating or urinating. The remaining $53.6 \%$ of respondents had 
the habit of defecating in open land, namely gardens, rivers, or swamps. 136 respondents $(60 \%)$ had the habit of defecating or urinating in the latrine or other facilities that did not meet health requirements. More than half of respondents (67.1\%) did not have a temporary waste disposal site, while $89.3 \%$ of respondents had temporary waste disposal sites that did not meet health requirements. The majority of the sewerage observed $(83.6 \%)$ did not meet health requirements. Residents need increased knowledge and awareness of the importance of basic home sanitation in maintaining family health. Support from various parties is also needed to improve community skills in processing river and swamp water into clean water.

\section{REFERENCES}

1. Ministry of Health of Republic Indonesia. Diarrhea Situation in Indonesia 2011. Jakarta: Ministry of Health of Republic Indonesia; 2011.

2. District Health Office of Ogan Ilir. Health Profile of Ogan Ilir 2015. Ogan llir: District Health Office of Ogan Ilir; 2015.

3. Ganiwijaya F, Rahardjo M. Sebaran Kondisi Sanitasi Lingkungan dengan Kejadian Diare pada Balita Menggunakan Sistem Informasi Geografis di Kecamatan Semarang Selatan. J Kesehat Masy. 2016;4(3):782-791. https://ejournal3.undip.ac.id/ index.php/jkm/article/view/13537

4. Lidiawati M. Hubungan Sanitasi Lingkungan dengan Angka Kejadian Diare pada Balita di Wilayah Kerja Puskesmas Meuraxa Tahun 2016. J SAINS APL. 2016;4(2):1-9. http://jurnal.serambimekkah.ac.id/ serambi-saintia/article/view/85

5. Heriyawan T. Kajian Kualitas Kesehatan Lingkungan Permukiman di Kecamatan Purwokerto Barat Kabupaten Banyumas dengan Menggunakan Citra Satelit IKONOS. J Bina Cipta Husada. 2020;16(1):21-31. https://doi.org/10.32672/jss. v4i2.85.

6. Utami N, Luthfiana N. Faktor-Faktor yang Memengaruhi Kejadian Diare pada Anak. Med J Lampung Univ. 2016;5(4):101-106. http://juke. kedokteran.unila.ac.id/index.php/majority/article/ view/893

7. Putra ADP, Rahardjo M, Joko T. Hubungan Sanitasi Dasar dan Personal Hygiene dengan Kejadian Diare pada Balita di Wilayah Kerja Puskesmas Tasikmadu Kabupaten Karanganyar. J Kesehat Masy. 2017;5(1):422-429. https://ejournal3.undip. ac.id/index.php/jkm/article/view/15791

8. Samiyati M, Soedarto JH. Hubungan Sanitasi Lingkungan Rumah dengan Kejadian Diare pada Balita di Wilayah Kerja Puskesmas Karanganyar Kabupaten Pekalongan. J Kesehat Masy. 2019 ;7(1):388-395. https://ejournal3.undip.ac.id/index. php/jkm/article/view/23008

9. Hastia S, Ginting T. Hubungan Sanitasi Lingkungan dan Personal Hygiene Ibu dengan Kejadian Diare pada Balita di Kelurahan Sidorejo Puskemas Sering Kota Medan. J Prima Med Sains. 2019;1(1):1217. http://jurnal.unprimdn.ac.id/index.php/JPMS/ article/view/728

10. Ministry of Health of Republic Indonesia. Regulation of Ministry of Health of Republic Indonesia No. 416 Year 1990 about Requirements and Control of Drinking Water. Jakarta: Ministry of Health of Republic Indonesia; 1990.

11. Soekidjo N. Ilmu Kesehatan Masyarakat. Jakarta: Rineka Cipta; 2003.

12. Destiya Kurniawati L. Faktor-Faktor yang Berpengaruh terhadap Perilaku Kepala Keluarga dalam Pemanfaatan Jamban di Pemukiman Kampung Nelayan Tambak Lorok Semarang 2015. Skripsi. Semarang: Universitas Negeri Semarang; 2015.

13. Amaliah S. Hubungan Sanitasi Lingkungan dan Faktor Budaya dengan Kejadian Diare pada Anak Balita di Desa Toriyo Kecamatan Bendosari Kabupaten Sukoharjo. In Prosiding Seminar Nasional dan Internasional Universitas Muhammadiyah Semarang. 2010;1(1):91$97 . \quad$ https://jurnal.unimus.ac.id/index.php/ psn12012010/article/view/52

14. Elizabeth T. Faktor-Faktor yang Mempengaruhi Partisipasi Keluarga dalam Penggunaan Jamban di Kota Kabanjahe Tahun 2007. Skripsi. Sumatera Utara: Universitas Sumatera Utara; 2008.

15. Rachman DN. Penggunaan Tripikon-S sebagai Alternatif Penggunaan Septic Tank di Daerah Tepian Sungai dan Rawa. J TEKNO Glob. 2016;5(1):4049. http://ejournal.uigm.ac.id/index.php/TG/article/ view/384

16. Sidhi AN, Raharjo M, Dewanti Nay. Hubungan Kualitas Sanitasi Lingkungan dan Bakteriologis Air Bersih terhadap Kejadian Diare pada Balita di Wilayah Kerja Puskesmas Adiwerna Kabupaten Tegal. J Kesehat Masy. 2016;4(3):665-676. https://ejournal3.undip.ac.id/index.php/ikm/article/ view/13480

17. Hakiki C, Soedjono ES. Strategy Towards $100 \%$ Open Defecation Free in Murung Keraton Village, Martapura District, Banjar Regency. IAETSD. 2019;6(2):1-5. $\quad$ www.iaetsdjaras.org/gallery/1february-876.pdf

18. Mahfoedz M. Menjaga Kesehatan Rumah dari Berbagai Penyakit. Yogyakarta: Fitramaya; 2004.

19. Winarti A, Nurmalasari S. Hubungan Perilaku Buang Air Besar (BAB) dengan Kejadian Diare di Desa Krajan Kecamatan Jatinom Kabupaten Klaten. J Kebidanan. 2016;7(12):13-25. http:// jurnal.stikesmukla.ac.id/index.php/involusi/article/ view/207

20. Langit LS. Hubungan Kondisi Sanitasi Dasar Rumah dengan Kejadian Diare pada Balita di Wilayah Kerja Puskesmas Rembang 2. J Kesehat Masy. 2016;4(2):160-165. https://ejournal3.undip. ac.id/index.php/jkm/article/view/11941

21. Rahayu Y, Juwana I, Marganingrum D. Kajian Perhitungan Beban Pencemaran Air Sungai di 
Daerah Aliran Sungai (DAS) Cikapundung dari Sektor Domestik. J Rekayasa Hijau. 2018;2(1):6171. https://doi.org/10.26760/jrh.v2i1.2043.

22. Djoharam V, Riani E, Yani M. Analisis Kualitas Air dan Daya Tampung Beban Pencemaran Sungai Pesanggrahan di Wilayah Provinsi DKI Jakarta. $J$ Pengelolaan Sumber Alam dan Lingkungan. 2018;8(1):127-133. https://jurnal.ipb.ac.id/index. php/jps//article/view/15349

23. Widyowati W, Syaputri AR, Febrianto D. Kebijakan Pemerintah Kota Denpasar terhadap Upaya Pencegahan Pencemaran Lingkungan Hidup di
Kota Denpasar. J Reformasi Huk. 2018 ;1(2):45-50. https://e-journal.umaha.ac.id/index.php/reformasi/ article/view/220

24. Waluya J, Hermanto H. Ketimpangan Permukiman di Daerah Aliran Sungai (DAS) Kali Sentiong Johar Baru Jakarta Pusat. J Ilmu Pendidikan Geografi. 2020;1(1):6-24. http://jurnal.unismabekasi.ac.id/ index.php/geographia/article/view/2462

25. Indriyani Y. Kajian Strategi Promosi Kesehatan Sanitasi Total Berbasis Masyarakat (STBM) Kelurahan Tirto Kecamatan Pekalongan Barat Kota Pekalongan. Unnes J Public Health. 2016;5(3):240251. https://doi.org/10.15294/ujph.v5i3.11286 